1961). The largest of the reports of committees is that of the Committee on Research, which includes lists of the 170 grants totalling 165,609 dollars made in 1960 from the Penrose Fund and of the 53 grants, totalling 53,473 dollars, made from the Johnson Fund. Four fellowships, totalling 27,400 dollars, were awarded from the Darland Fund. Reports from recipients of grants occupy almost 400 pages of the 416 of the Committee's report. Among the biographical memoirs included in the volume may be mentioned those on R. C. Andrews, W. H. W. Baade, N. L. Bowen, O. E. Buckley, A. L. Day, Sir Walter Wilson Grey, M. von Laue, L. Loeb, S. A. Mitchell and E. C. Tolman.

\section{Cigarette Smoke Condensate}

THE Tobacco Manufacturers' Standing Committee has published a second edition of its Research Paper No. 4, Cigarette Smoke Condensate: Preparation and Routine Laboratory Estimation (by H. R. Bentley and J. G. Burgan. London, 1961). This largely follows the first edition published in 1959, which it super sedes; but in the new edition the section referring to routine laboratory estimation of the yield of cigarette smoke condensate has been revised and extended. The standard method given in the first edition has been modified in the light of experience in order to improve the reproducibility of results. In particular, collection of smoke particulate matter by means of a 'Cambridge' filter followed by drying to constant weight is recommended for general use on grounds of simplicity, in preference to electrostatic precipitation, which has been found to have some disadvantages for quantitative work. Consideration is also given to the definition of realistic smoking conditions to bo used with automatic smoking machines, and paramoters, based on observations of smokers, of one puff of 2 -sec. duration and $25-\mathrm{ml}$. vol./min., are recommended. These values are useful to have, for it would clearly be an advantage if some such agreed parameters were to be adopted in all laboratories in the United Kingdom in which cigarette smoke is being prepared and investigated.

\section{Colour in Factories}

CoLour in industry is not merely a form of decoration or even a welfare measure. It has certain functions to perform and the factors important for success have been established. The latest report in the Factory Building Studies series, based on several years work on the use of colour in various types of building, is a concise guide for factory managements and their architects or colour consultants (Factory Buildings Studies No. 8. Colouring in Factories. Published for D.S.I.R. by H.M.S.O. Price $7 s .6 d$., postage $4 d$.). It has two sections, both containing coloured illustrations. The first section describes the basic properties and effects of colour, linking them with certain facts about human eyesight, to form general principles of colour design. The second section explains the practical application of these principles. It indicates stage by stage the way in which colour for each element of the interior becomes disciplined so that a picture is formed of the characteristics essential to good factory colouring. The examples are mainly for daylight, but there are notes on the special problems arising where lighting is wholly or partly artificial. As lighting and colouring are interrelated, this work is complementary to the earlier work (No. 2 in the series) on The Lighting of Factories.

\section{The Content of Jobs}

To the steadily growing number of broadsheets which are being produced to assist all who are concerned with the personnel function of management, the Institute of Personnel Management has now issued one called Job Analysis. Prepared by H. E. Roff and T. E. Watson, of Management Selection, Ltd., the broadsheet defines job analysis as "the scientific study of statements of all the facts about a job which reveal its content and all the modifying factors which surround it". Accepting that much of what passes for job analysis to-day is scarcely scientific, the authors show how a systematic approach to the analysis of a job can help all those who have to deal with human problems arising from the establishment of wage or salary scales, and the intricacies of selection, training and safety. Great difficulties confront industrial management in classifying one job against another and the method described in Job Analysis provides a useful modus operandi. For detailed information the reader must seek elsewhere, and the broadsheet contains a valuable bibliography which will help him to do this. Job Analysis is obtainable from the Institute of Personnel Management, Management House, 80 Fetter Lane, London, E.C.4, price 7s. $6 d$.

\section{European Organic Geochemistry Group}

Ar a recent meeting of members of various European geochemistry groups it was proposed that a European section of the Organic Geochemistry Group of the Geochemical Society should be formed. At present the Organic Geochemistry Group has 250 members, 45 of whom are resident in Europe. The Group held very successful meetings in Denver last autumn, and this year meetings are to be held in Cincinnati. As such, countries interested in such an organization include Italy, France, the United Kingdom, Germany and Holland. The possibility of a meeting in Milan during September 1962 is being considered. Persons interested in such an organization should write to Dr. G. D. Hobson, Department of Geology, Imperial College of Science and Technology, Prince Consort Road, London, S.W.7.

\section{Oliver Memorial Fund Award for Blood Transfusion Work}

THe Committee of the Oliver Memorial Fund intends making its fourteenth annual award of the value of $£ 50$ to a British subject whose original work, or services in connexion with blood transfusion, is considered to be a notable contribution to the research organization or donor aspect of this subject. The Committee will welcome applications and, in addition, communications directing its attention to suitable candidates. Applications should be submitted before September 30 , and should be sent to the honorary secretary, Mrs. F. E. Bedborough, 105 New Park Avenue, London, N.13.

\section{Australian Post-Doctoral Fellowships in Protein Chemistry}

THe Division of Protein Chemistry of the Commonwealth Scientific and Industrial Research Organization, Australia, is offering a number of post-doctoral fellowships. The Division has been engaged on a comprehensive research programme on protein structure and chemistry for the past twelve years covering chemical, physicochemical, biophysical and 